

Kamil Decyk

Uniwersytet Warmińsko-Mazurski w Olsztynie
DOI $10.22630 /$ PEFIM.2020.24.73..27

Otrzymany: 12.11.2019

Zaakceptowany: 24.09.2020

\title{
Potencjał produkcyjny sektora usług w krajach członkowskich Unii Europejskiej
}

\section{PRODUCTION POTENTIAL OF SERVICE SECTOR IN EU MEMBER STATES}

\begin{abstract}
Zaprezentowane $w$ artykule wynik badań wtasnych bazują na danych wtórnych pozyskanych z europejskiej bazy - Eurostat. Treści przedstawione w opracowaniu dotycza problematyki szeroko rozumianej produktywności sektora usług, stanowiacej czesść badań, które w petnym podejściu badawczym poszerzone sa jeszcze o aspekt innowacyjności ww. sektora. W nawiazaniu do poruszanej $w$ badaniach tematyki, za problem badawczy przyjęto role i znaczenie sektora ustug $w$ gospodarkach państw Unii Europejskiej $w$ XXI w. W tej perspektywie jednym z celów prowadzonych badań byta m.in. identyfikacja potencjału produkcyjnego charakteryzujacego sektor usług państw członkowskich Unii Europejskiej. Do realizacji ww. celu wykorzystano wspomniana metodę analizy danych wtórnych, przegląd literatury krajowej i zagranicznej $z$ zakresu omawianej tematyki, a także metody statystyczne $w$ postaci statystyki podstawowej (średnia arytmetyczna, odchylenie standardowe), które szczególne zastosowanie miały podczas agregowania państw do grup o określonym potencjale produkcyjnym sektorów usług.

Rozpatrując wszystkie wskaźniki potencjału produkcyjnego analizowane $w$ artykule (liczba przedsiębiorstw, liczba zatrudnionych, wartość produkcji) wśród krajów UE, sektorem ustug o najwyższym potencjale produkcyjnym charakteryzowaty się: Francja, Wielka Brytania, Niemcy, Wtochy, Niemcy oraz Hiszpania - z wyjątkiem wartości produkcji. Polska zaklasyfikowana zostata do państw o średnim potencjale z wyjątkiem wskaźnika określającego wartość produkcji-poziom niski.
\end{abstract}

Słowa kluczowe: potencjał produkcyjny, produktywność, sektor usług, kraje członkowskie UE JEL Codes: D24, L80, O52

\section{Wprowadzenie}

Usługa poza wyrobem gotowym jest jedną z form produktów, które są oferowane przez przedsiębiorstwa w wyniku prowadzonej przez nie działalności gospodarczej. Wszystkie podmioty gospodarcze, które świadczą usługi na terenie danego państwa lub poza jego granicami tworzą tzw. sektor usług. Smid ${ }^{1}$ zdefiniował pojęcie sektora, jako zbioru przedsiębiorstw, prowadzących tą samą działalność podstawową, czyli zajmujących się wytwarzaniem wyrobów bądź usług o podobnym przeznaczeniu. Do sektora usługowego zaliczane są tzw. sekcje gospodarki narodowej danego państwa, oznaczone umownie literami alfabetu.

\footnotetext{
${ }^{1}$ Smid W.: Leksykon przedsiębiorcy. Poltext, Warszawa, 2010, s. 216.
} 
Zgodnie z podejściem teoretycznym do gospodarki dzieli się ona na trzy sektory: rolniczy, przemysłowy oraz usługowy (tzw. trzeci sektor). Zwolennicy tej koncepcji, m.in. Fouratsie, Fisher oraz Clark ${ }^{2}$ wskazywali na zmianę wymienionych sektorów w perspektywie rozwoju cywilizacyjnego. Ich zdaniem jednocześnie z rozwojem gospodarczym rosła produktywność $\mathrm{w}$ rolnictwie, a także występowało nasycenie popytu. Pozwalało to $w$ efekcie na uwolnienie nadwyżki siły roboczej zatrudnianej w przemyśle. Zgodnie z tą koncepcją, analogiczne zależności powodowały przesunięcie zatrudnienia do sektora usług. Tego typu przemieszczenia $\mathrm{z}$ teoretycznego punktu widzenia są niebezpieczne ze względu na nasycenie popytu oraz uwalnianie siły roboczej w sektorze trzecim, która jednak nie znajduje zatrudnienia w nieistniejącym sektorze czwartym ${ }^{3}$. Zgodnie z Riddlem, Ott'em czy Markiem i Kravisem ${ }^{4}$, efektywny rozwój sektora trzeciego oraz wzrost jego wpływu na całą gospodarkę możliwy jest tylko wówczas, gdy interwencjonizm państwowy ograniczony jest do minimum. Co więcej, w literaturze wskazuje się, że w przypadku sektora usług nie wystąpią ograniczone możliwości rozwoju gospodarczego. Wynika to po pierwsze z obecności usług rządowych, a nie tylko konsumpcyjnych (które mają ograniczone możliwości ewolucji), a po drugie z korzystnych warunków rozwojowych przedsiębiorstw podejmujących działania w zakresie innowacyjnych technologii. W perspektywie szerokiego zainteresowania problematyką sektora usług i ukierunkowania działań wielu krajów Unii Europejskiej (UE) w jej kierunku, interesującymi aspektami wydają się być wszelkie wielkości i wartości ekonomiczne pozwalające scharakteryzować jego specyfikę. Z tego względu wopracowaniu przedstawiono wyniki badań łączące problematyki produktywności z sektorem usług. Stanowić one mogą jeden $\mathrm{z}$ wielu sposobów wyjaśnienia problemu badawczego w postaci: roli i znaczenia sektora usług w gospodarkach krajów w XXI w. W perspektywie wzrostu gospodarczego sektor ten nabiera coraz większego znaczenia i wpływa na sytuację ekonomiczną wszystkich krajów europejskich. W myśl tak przedstawionego problemu, za cel opisywanych badań przyjęto identyfikację potencjału produkcyjnego charakteryzującego sektor usług państw członkowskich UE. Do realizacji przedstawionego założenia posłużyły trzy metody badawcze. Pierwszą z nich była analiza i krytyka piśmiennictwa krajowego oraz zagranicznego. Na jej podstawie przedstawiono problematykę potencjału produkcyjnego i produktywności w świetle teoretycznym. Drugą z zastosowanych metod była analiza danych wtórnych z bazy danych statystycznych Eurostat. Trzecią metodę stanowiły metody statystyczne (statystyka opisowa - średnia arytmetyczna, odchylenie standardowe), które szczególne zastosowanie miały podczas agregowania państw UE do grup o określonym potencjale produkcyjnym sektorów usług. W ten sposób zidentyfikowano 4 poziomy, które szczegółowo zostaną opisane w dalszej części

\footnotetext{
${ }^{2}$ Fourastie J.: Die Grosse Hoffnung des zwanzigsten Jahrhunderts. Bund-Verlag, Köln-Deutz, 1954, s. 126-137; Fischer A.: Economic Progress and Social Security. Macmillan, London, 1945, s. 8; Clark C.: The Conditions of Economic Progress. Macmillan, London, 1957, s. 492

${ }^{3}$ Rogoziński P.: Ustugi rynkowe. Poznań: Wydawnictwo Akademii Ekonomicznej w Poznaniu, Poznań, 2000, s. 93.

${ }^{4}$ Cyrek M.: Wspótczesne zmiany struktury sektora ustugowego, [w:] Funkcjonowanie gospodarki polskiej w warunkach integracji i globalizacji, red. D. Kopycińska, Katedra Mikroekonomii, Uniwersytet Szczeciński, Szczecin 2005, s. 281.
} 
opracowania. Do badań wykorzystano również narzędzie statystyczne, którym był program Statistica w wersji 13.

Zgodnie z założeniami metodycznymi europejskiej bazy danych Eurostat ${ }^{5}$, rodzaje działalności zaliczane do sektora usług oznaczono symbolami $\mathrm{H}-\mathrm{N}$ oraz dział $95 \mathrm{z}$ sekcji S (klasyfikacja zgodna z PKD z 2007 r.) ${ }^{6}$. Poszczególne sekcje sektora usług stanowiły podmiot prowadzonych badań. Opisane w opracowaniu badania stanowią część kompleksowych badan prowadzonych w sektorze usług dotyczących jego innowacyjności oraz produktywności. Z uwagi na znaczące braki w danych dotyczących ww. aspektów, sekcja K oraz dział 95 sekcji S zostały pominięte w analizach.

W celu scharakteryzowania sektora usług krajów członkowskich UE dokonano identyfikacji oraz przeprowadzono analizy dotyczące wskaźników (indykatorów, czynników) świadczących o ich potencjale produkcyjnym:

- liczba przedsiębiorstw (w tys.),

- liczba zatrudnionych (w tys. osób),

- wartość produkcji (w mln euro),

$\mathrm{Na}$ podstawie wymienionych wskaźników dokonano agregacji państw UE do jednego z czterech poziomów (bardzo niskiego, niskiego, średniego, wysokiego) ze względu na potencjał produkcyjny. Do klasyfikacji tej wykorzystano kryterium grupowania krajów ze względu na syntetyczną miarę potencjału sektora usług. Na podstawie średniej arytmetycznej oraz odchylenia standardowego określono wspomniane wcześniej cztery poziomy każdego z rozpatrywanych wskaźników (tab. 1).

Tabela 1. Kryteria grupowania krajów ze względu na syntetyczną miarę potencjału sektora usług

\begin{tabular}{|c|c|c|}
\hline Poziom & Podstawa grupowania & Opis \\
I & $\mathrm{d}_{\mathrm{i}} \geq \overline{\mathrm{d}}+\mathrm{S}_{\mathrm{d}}$ & bardzo niski poziom danego wskaźnika \\
II & $\overline{\mathrm{d}}<\mathrm{d}_{\mathrm{i}} \leq \overline{\mathrm{d}}+\mathrm{S}_{\mathrm{d}}$ & niski poziom danego wskaźnika \\
III & $\overline{\mathrm{d}}-\mathrm{S}_{\mathrm{d}}<\mathrm{d}_{\mathrm{i}} \leq \overline{\mathrm{d}}$ & średni poziom danego wskaźnika \\
IV & $\mathrm{d}_{\mathrm{i}}<\overline{\mathrm{d}}-\mathrm{S}_{\mathrm{d}}$ & wysoki poziom danego wskaźnika \\
\hline
\end{tabular}

Źródło: Opracowanie własne na podstawie (Wysocki, Lira 2003, s. 176)

Dane charakteryzujące potencjał produkcyjny pozyskano z okresu 2008-2016. Do ich analizy wykorzystano wskaźnik dynamiki, w ramach którego określono charakter zmian (malejące, rosnące) zachodzące w zakresie wymienionych trzech wskaźników potencjału produkcyjnego w $2016 \mathrm{r}$. w stosunku do $2008 \mathrm{r}$.

\section{Produktywność a sektor usług - rozważania teoretyczne}

Aktualnie dynamicznie ewoluuje tzw. ,serwicyzacja”, czyli zwiększenie roli i znaczenia sektora usługowego $\mathrm{w}$ procesie rozwoju społeczno-gospodarczego $\mathrm{w}$ stosunku do sektora przemysłowego oraz rolnego. Zjawisko takie zauważono w Stanach Zjednoczonych już w latach 70. XX w., a aktualnie obserwowalne jest także w Japonii, a także państwach członkowskich UE. Bezpośrednie oddziaływanie sektora usług widoczne jest $\mathrm{w}$ zakresie wspomnianej struktury społeczno-gospodarczej kraju, a także w parametrach takich, jak np. miejsca prac czy też produkt krajowy brutto (PKB), który

${ }^{5}$ Eurostat [sbs_na_1a_se_r2], dostęp on-line dn. 21.03.2019 r. 
w znacznej części jest wynikiem działalności podmiotów świadczących usługi. Należy zauważyć także jego pośrednie znaczenie przejawiające się we wzroście produktywności pozostałych sektorów gospodarki ${ }^{7}$. Proces budowy gospodarki opartej na wiedzy (GOW) zgodnie z Uliszak i Grad ${ }^{8}$, w zdecydowanej mierze bazuje na rozwoju nowoczesnego sektora usług, a także innowacyjnego sektora przemysłowego.

Zróżnicowanie działalności usługowej powoduje powstawanie wielu kryteriów klasyfikacji. Jedno z nich wyróżnia trzy grupy usług:

- konsumpcyjne - świadczone indywidualnym osobom, ich obiektem oddziaływania jest użytkownik usługi w postaci osoby fizycznej,

- producenckie - wykonywane na rzecz producentów, obsługujące procesy produkcyjne i będące pośrednim czynnikiem wytwarzania dóbr materialnych,

- rządowe - dostarczane są przez państwo, mają charakter publiczny (opłacana $\mathrm{z}$ budżetu państwa) ${ }^{9}$.

Innym kryterium różnicującym działalność usługową jest poziom wykorzystania wiedzy $\mathrm{i}$ technologii. W tym zakresie wyszczególnia się usługi tradycyjne oraz nowoczesne. Pierwsze $\mathrm{z}$ wymienionych charakteryzują się stosunkowo mniejszą dynamiką wzrostu produkcyjności i większą intensywnością nakładów pracy (ludzi o niższych lub średnich kwalifikacjach). Zgodnie $\mathrm{z}$ taką interpretacją, do usług tradycyjnych można zaliczyć: usługi dystrybucyjne, turystyczne, rekreacyjne, socjalne, a także niektóre transportowe ${ }^{10}$. Państwa, w których dominuje taka struktura sektora usługowego wolniej tworzą gospodarkę opartą na wiedzy oraz wykazują zdecydowanie niższy poziom innowacyjności. W konsekwencji, słabo rozwinięte usługi związane z prosperowaniem nowoczesnych gospodarek destymulują oraz powstrzymują przekształcenia strukturalne i tym samym utrudniają osiągnięcie przewagi konkurencyjnej ${ }^{11}$. Usługi określane jako nowoczesne mają odwrotną specyfikę w stosunku do tradycyjnych. Cechują się wysokim poziomem i tempem wzrostu produkcyjności oraz dużym udziałem wysoko wykwalifikowanego kapitału ludzkiego. Zaliczyć do nich można m.in.: usługi finansowe, ubezpieczeniowe, niektóre biznesowe i profesjonalne, a także ICT (Information and Communication Technologies), czyli informatyczne oraz komunikacyjne w tym także informacyjne.

W dotychczas zaprezentowanych rozważaniach można zauważyć, że problematykę sektora usług należy w wielu aspektach powiązywać z jego produktywnością, której sposób wyliczania jest wyrażony relacją, zachodząca między ilością wytwarzanej oraz sprzedanej produkcji, a czynnikami produkcji wykorzystywanymi do jej wytworzenia. Przedstawiciele klasycyzmu uznawali, że produkt (wyrób czy usługa) był efektem

\footnotetext{
${ }^{7}$ Skórska A.: Determinanty i perspektywy rozwoju sektora ustug w Polsce - zmiany wewnatrzsektorowe [w:] Prace Komisji Geografii Przemysłu Polskiego Towarzystwa Geograficznego., 30(4). Przemiany sektora usług transportowych i turystycznych, red. Z. Zioło, T. Rachwała, Wydawnictwo Uniwersytetu Pedagogicznego im. Komisji Edukacji Narodowej w Krakowie, Kraków, 2016, s. 8.

${ }^{8}$ Uliszak R., Grad N.: Innowacyjność kluczem rozwoju firmy IBM. Prace Komisji Geografii Przemysłu Polskiego Towarzystwa Geograficznego, 20/2012, s. 40-41.

${ }^{9}$ Cyrek M.: Wspótczesne zmiany struktury sektora ustugowego, [w:] Funkcjonowanie gospodarki polskiej w warunkach integracji i globalizacji, red. D. Kopycińska, Katedra Mikroekonomii, Uniwersytet Szczeciński, Szczecin 2005, s. 279.

${ }^{10}$ Węgrzyn G., Miłaszewicz D.: Sektor usług w gospodarce opartej na wiedzy - analiza porównawcza. Studia i Prace Wydziału Nauk Ekonomicznych i Zarządzania Uniwersytetu Szczecińskiego 47/3, 2017, s. 437-438.

${ }^{11}$ Ibidem, 2017, s. 434.
} 
synergicznego zastosowania trzech czynników wytwórczych, do których zaliczono: ziemię, pracę i kapitał ${ }^{12}$. Klasyczny układ czynników produkcji został nieznacznie zmodyfikowany przez Roberta Solowa i Trevora Swane'a w 1956 r. W modelu długookresowego wzrostu zamiast ziemi pojawił się czynnik związany z technologią, który wszedł w skład agregatowej funkcji produkcji ${ }^{13}$.

Produktywność rozumiana jako stopień wykorzystania czynników wytwórczych w relacji do efektów osiągniętych w wyniku ich stosowania, stanowi jedną z kilku miar efektywności wykorzystania wszystkich zasobów będących w dyspozycji państwa czy też przedsiębiorstwa ${ }^{14}$. Wierzbicka ${ }^{15}$ uważa, że produktywność rozumiana $\mathrm{w}$ ten sposób powinna być jednym $\mathrm{z}$ podstawowych kryteriów oceny funkcjonowania systemów wytwórczych w krajach wysoko rozwiniętych. Każdy system produkcyjny zgodnie z podejściem klasycznym charakteryzuje się zbiorem zasobów wejściowych, procesami (podstawowymi oraz pomocniczymi) w nim zachodzącymi, a także zbiorem produktów. Dodatkowo występuje możliwość określenia jego poziomu produktywności. Wśród elementów wejściowych, które stanowią tzw. potencjał produkcyjny i w kolejnych etapach ulegają przekształceniom, wymienić należy m.in. wyposażenie produkcyjne, materiały, kapitał, ludzi, energię, wiedzę, informację itp. Efekty tak interpretowanego systemy produkcyjnego mogą być różnorodne. Zaliczyć można do nich przykładowo wyroby czy usługi, ale także odpady produkcyjne czy informacje $\mathrm{e}^{16}$.

\section{Wyniki badań}

\section{Liczba podmiotów i zatrudnionych sektora usług w krajach UE}

$\mathrm{Na}$ podstawie danych pochodzących z bazy Eurostatu, które dotyczą sektora usług w krajach UE, stworzono zestawienie państw w zakresie liczby przedsiębiorstw sektora usług (tab. 2). Zgodnie $\mathrm{z}$ zaprezentowanymi informacjami $\mathrm{w}$ badanym okresie we wszystkich państwach UE wystąpił wzrost dynamiki analizowanego wskaźnika. Największy, niemal siedmiokrotny $(698,2 \%)$ przyrost liczby podmiotów zaobserwowano na Słowacji. Drugim krajem, w którym odnotowano znaczny wzrost opisywanego wskaźnika była Holandia - dynamika 234,5\%. Na podstawie tych danych można zaobserwować, że w tych krajach w badanym okresie wystąpiła znaczna poprawa warunków do tworzenia nowych przedsiębiorstw usługowych.

W przypadku Słowacji niemal siedmiokrotny wzrost liczby podmiotów w badanym okresie w głównej mierze był efektem nieco ponad pięciokrotnego przyrostu w latach 2008-2012. Związany on był przede wszystkim ze znaczącą deregulacją gospodarki,

\footnotetext{
${ }^{12}$ Bartkowiak R.: Historia myśli ekonomicznej. Wydawnictwo PWE< Warszawa, 2003, s. 42.

${ }^{13}$ Zielińska-Głębocka A.: Analiza produkcyjności polskiego przemystu. Aspekty metodyczne i empiryczne. Ekonomista, 3/2004, s. 337.

14 Kozioł L.: Metodyczne aspekty oceny produktywności. Zeszyty Naukowe Akademii Ekonomicznej w Krakowie, 727, 2007, s. 25; Dudziak A., Piekarski W., Stoma M.: Zarządzanie produktywnościa a ryzyko operacyjne działalności polskich przedsiębiorstw, monografia pokonferencyjna: „Innowacje w Zarządzaniu i Inżynierii Produkcji”, Zakopane, 2014, s. 240.

${ }^{15}$ Wierzbicka W.: Produktywność pracy przedsiębiorstw prywatnych $w$ Polsce - ujęcie regionalne. Zeszyty Naukowe Uniwersytetu Przyrodniczo-Humanistycznego w Siedlcach, Seria: Administracja i Zarządzanie, 97, 2013, s. 242.

${ }_{16}$ Smoleński S.: Zarządzanie produktywnościa $w$ przedsiębiorstwie. Wydawnictwo Ośrodek Postępu Organizacyjnego, Bydgoszcz, 2000, s. 38.
} 
a także ze skutkami kryzysu gospodarczego. Tak gwałtowny wzrost liczby podmiotów można także tłumaczyć akcesją Słowacji do strefy euro. To stwierdzenie potwierdza również dynamika wartości państw, które w okresie objętym badaniami przyjęły wspólną europejską walutę, tj.: Estonia (2011 r.), Łotwa (2014 r.) czy Litwa (2015 r.). Wzrost liczby przedsiębiorstw w tych krajach był znacznie większy niż w innych państwach wschodniej Europy, np. Polsce, Rumunii, Bułgarii czy Czechach, które nie wprowadziły waluty euro.

Tabela 2. Liczba przedsiębiorstw sektora usług w krajach UE (w tys.)

\begin{tabular}{|c|c|c|c|c|c|}
\hline \multirow[t]{2}{*}{ Lp. } & \multirow{2}{*}{ Wyszczególnienie } & \multicolumn{3}{|c|}{ Rok } & \multirow{2}{*}{ Dynamika 2016/2008 (\%) } \\
\hline & & 2008 & 2012 & 2016 & \\
\hline 1 & Włochy & 1594 & 1626 & 1670 & 104,7 \\
\hline 2 & Francja & 1037 & 1368 & 1490 & 143,6 \\
\hline 3 & Hiszpania & 1185 & 1107 & 1299 & 109,6 \\
\hline 4 & Niemcy & 982 & 1115 & 1296 & 131,9 \\
\hline 5 & Wielka Brytania & 921 & 947 & 1270 & 137,8 \\
\hline 6 & \begin{tabular}{|l|} 
Polska \\
\end{tabular} & 518 & 566 & 698 & 134,7 \\
\hline 7 & Holandia & 272 & 461 & 639 & 234,5 \\
\hline 8 & Portugalia & 450 & 397 & 455 & 101,1 \\
\hline 9 & Szwecja & 320 & 375 & 406 & 126,9 \\
\hline 10 & Czechy & 375 & 388 & 401 & 107,0 \\
\hline 11 & Grecja & 338 & 306 & 382 & 113,0 \\
\hline 12 & Belgia & 194 & 283 & 338 & 174,1 \\
\hline 13 & Węgry & 284 & 271 & 292 & 103,0 \\
\hline 14 & Rumunia & 171 & 157 & 188 & 109,9 \\
\hline 15 & Austria & 157 & 170 & 179 & 114,2 \\
\hline 16 & Słowacja & 24 & 123 & 171 & 698,2 \\
\hline 17 & Bułgaria & 95 & 118 & 138 & 144,6 \\
\hline 18 & Irlandia & 114 & 123 & 127 & 111,8 \\
\hline 19 & Dania & 108 & 116 & 123 & 114,3 \\
\hline 20 & Finlandia & 105 & 110 & 120 & 113,7 \\
\hline 21 & Litwa & 46 & 48 & 77 & 165,2 \\
\hline 22 & Słowenia & 46 & 55 & 71 & 152,5 \\
\hline 23 & Chorwacja & 68 & 63 & 70 & 103,5 \\
\hline 24 & Łotwa & 36 & 46 & 61 & 168,8 \\
\hline 25 & Estonia & 22 & 29 & 35 & 159,9 \\
\hline 26 & Cypr & 16 & 17 & 20 & 124,4 \\
\hline 27 & Luksemburg & 15 & 17 & 19 & 128,4 \\
\hline 28 & Malta & 11 & 10 & 13 & 115,8 \\
\hline
\end{tabular}

Źródło: Opracowanie własne na podstawie danych Eurostatu [sbs_na_1a_se_r2] (11.04.2019).

Na Słowacji, w latach 2012-2016, przyrost podmiotów usługowych był mniejszy niż w okresie 2008-2012 i przypuszczalnie mógł wynikać z poziomu kształtowania się głównych wskaźników makroekonomicznych np.: wielkości PKB per capita, stopy inflacji, a także wartości obrotów oraz tempa wzrostu handlu zagranicznego. Wszystkie te wskaźniki w latach 2011-2016 wykazywały pozytywne trendy i sprzyjały powstawaniu nowych przedsiębiorstw. Od 2014 r. gospodarka zaczęła osiągać nawet deflację, w przytoczonym roku na poziomie $-0,1^{17}$. Stan niskiej inflacji natomiast

${ }^{17}$ Gospodarka Stowacji w pierwszym kwartale 2016 r. Urząd Statystyczny RS, Narodowy Bank Słowacji, Ministerstwo Finansów Republiki Słowackiej, dostęp on-line dn. 16.05.2019 r.: https://bratyslawa.msz.gov.pl/ 
utrzymywał się aż do 2019 r. W kontekście wielkości PKB, największy udział wartościowy poza przemysłem $(27,8 \%)$ miały sekcje usługowe, do których zaliczono np.: handel, hotelarstwo, gastronomię i transport (19,6\%). Na czwartym miejscu sklasyfikowano usługi $\mathrm{w}$ zakresie nauki i administracji, na szóstym natomiast pośrednictwo w zakresie nieruchomości (3,9\%). Wysoki udział tych sekcji w tworzeniu PKB można wyjaśniać rozwiniętym handlem zagranicznym (stałe tempo wzrostu importu oraz eksportu) oraz potencjałem turystycznym Słowacji. Ten ostatni czynnik miał odzwierciedlenie m.in. w ruchu turystycznym. W 2015 r. z usług związanych m.in. z zakwaterowaniem skorzystało 1,73 mln osób $\mathrm{z}$ zagranicy, tj. wzrost o $17,1 \%$ w stosunku do 2014 r. Wliczając do tej statystyki także Słowaków, przedsiębiorstwa z tej sekcji „obsłużyły” aż 4,33 mln osób.

Najwięcej podmiotów gospodarczych z sektora usług wśród wszystkich krajów UE zarejestrowanych było we Włoszech - 1670 tys., w których w 2016 r. liczba przedsiębiorstw uległa nieznacznemu wzrostowi w stosunku do wcześniej omawianych krajów - dynamika 104,7\%. Jednocześnie był to jeden z czterech krajów charakteryzujący się najniższą dynamiką, sklasyfikowany tuż przed Portugalią $(101,1 \%)$, Węgrami $(103,0 \%)$ i Chorwacją $(103,5 \%)$. Wśród państw UE, które miały jedną z większych liczb podmiotów w 2016 r., największą dynamiką charakteryzowała się Holandia, a także Francja - 143,6\%, a następnie Wielka Brytania - 137,8\% oraz Polska - 134,7\%. Holandia była ostatnim z tzw. „siódemki” państw dominujących pod względem liczby przedsiębiorstw w sektorze usługowym.

Kolejnym wskaźnikiem świadczącym o potencjale produkcyjnym państw UE, poza liczbą przedsiębiorstw, była liczba zatrudnionych osób w sektorze usług wyrażona w tys. osób (tab. 3). Rozpatrując wszystkie kraje unijne w zakresie tego wskaźnika należy zauważyć, że każdy z nich charakteryzował się dynamiką wzrostową. Interesujące jest to, że pierwsze siedem krajów z największą liczbą zatrudnionych w 2016 r. było takie same jak w przypadku wskaźnika liczby podmiotów. W zaprezentowanym w tabeli 3 zestawieniu, różniły się one między sobą jedynie zajmowanymi miejscami. Państwem unijnym, w którym w 2016 r. odnotowano największą liczbę zatrudnionych w sektorze usług były Niemcy - 12591 tys. osób. Kolejne pozycje zajęły m.in.: Wielka Brytania, Francja, Włochy czy Hiszpania. Hierarchia państw pod względem liczby zatrudnionych prezentowała się analogicznie w latach 2008 oraz 2012. Tak jak mogło się intuicyjnie wydawać zauważono związek, że tym większe zatrudnienie w usługach, im więcej ludności zameldowanych $\mathrm{w}$ danym państwie.

Zgodnie z danymi Eurostatu ${ }^{18}$ z 2016 r., największa liczba ludności zamieszkiwała Niemcy - 82175 tys. osób, co stanowi 16,1\% mieszkańców UE. Druga w tej klasyfikacji była Francja - 66638 tys. osób $(13,1 \%)$, a trzecia Wielka Brytania - 65379 tys. osób (12,8\%). Wśród pierwszych siedmiu krajów z największą liczbą zatrudnionych, Niemcy charakteryzowały się najwyższą dynamiką na poziomie $138,4 \%$. Druga pod tym względem była Polska ze wzrostem wskaźnika o 22,3\% w stosunku do 2008 r.

pl/c/MOBILE/wspolpraca_dwustronna/wspolpraca_gospodarcza/sytuacja_gospodarcza/gospodarka_slowacji_ w_pierwszym_kwartale_2016_roku; Dane Eurostatu: https://ec.europa.eu/eurostat/tgm/table.do?tab=table \&language $=$ en \&pcode=tec00118\&tableSelection=1\&footnotes=yes\&labeling=labels\&plugin=1, dostęp online dn. 16.05.2019 r.

${ }^{18}$ Dane Eurostatu: https://ec.europa.eu/eurostat/tgm/table.do?tab=table\&language $=$ en $\& p c$ ode=tps00001\&table Selection $=1 \&$ footnotes $=$ yes\&labeling=labels\&plugin $=1$, dostęp on-line dn. 16.05.2019 r. 
Poza wspomnianymi krajami oraz Wielką Brytanią (dynamika 119,1\%) wśród pierwszych siedmiu państw, liczba osób zatrudnionych w sektorze usług nie ulegała dużym wahaniom. W całej klasyfikacji jednak dominowała dynamika odnotowana na Słowacji. W sektorze usług tego kraju zanotowano wzrost liczby osób zatrudnionych o 209 tys. w 2016 r. w stosunku do 2008 r. Stanowiło to jednocześnie przyrost na poziomie $71,3 \%$, który był największym wśród wszystkich krajów unijnych.

Tabela 3. Liczba zatrudnionych sektora usług w krajach UE (w tys. osób)

\begin{tabular}{|c|c|c|c|c|c|}
\hline \multirow{2}{*}{ Lp. } & \multirow{2}{*}{ Wyszczególnienie } & \multicolumn{3}{|c|}{ Rok } & \multirow{2}{*}{ Dynamika 2016/2008 (\%) } \\
\hline & & 2008 & 2012 & 2016 & \\
\hline 1 & Niemcy & 9094 & 10564 & 12591 & 138,4 \\
\hline 2 & Wielka Brytania & 8966 & 8869 & 10680 & 119,1 \\
\hline 3 & Francja & - & 6872 & 7144 & $104,0^{*}$ \\
\hline 4 & Włochy & 5680 & 5532 & 5831 & 102,7 \\
\hline 5 & Hiszpania & 5287 & 4796 & 5370 & 101,6 \\
\hline 6 & Holandia & 2779 & 2642 & 2902 & 104,4 \\
\hline 7 & Polska & 2278 & 2396 & 2788 & 122,3 \\
\hline 8 & Szwecja & 1206 & 1302 & 1468 & 121,7 \\
\hline 9 & Belgia & 994 & 1172 & 1322 & 133,0 \\
\hline 10 & Portugalia & 1270 & 1142 & 1316 & 103,7 \\
\hline 11 & Rumunia & 1122 & 1123 & 1280 & 114,1 \\
\hline 12 & Czechy & 1061 & 1056 & 1160 & 109,3 \\
\hline 13 & Austria & 1003 & 1070 & 1139 & 113,6 \\
\hline 14 & Grecja & 992 & 851 & 1138 & 114,7 \\
\hline 15 & Węgry & 957 & 925 & 1064 & 111,1 \\
\hline 16 & Dania & 662 & 622 & 756 & 114,1 \\
\hline 17 & Irlandia & 605 & 550 & 667 & 110,1 \\
\hline 18 & Bułgaria & 557 & 595 & 665 & 119,2 \\
\hline 19 & Finlandia & 555 & 582 & 613 & 110,3 \\
\hline 20 & Słowacja & 293 & 420 & 503 & 171,3 \\
\hline 21 & Chorwacja & 352 & 338 & 359 & 102,0 \\
\hline 22 & Litwa & 293 & 281 & 347 & 118,4 \\
\hline 23 & Łotwa & 234 & 219 & 267 & 114,4 \\
\hline 24 & Słowenia & 185 & 184 & 209 & 112,7 \\
\hline 25 & Estonia & 145 & 146 & 159 & 109,5 \\
\hline 26 & Luksemburg & 109 & 116 & 133 & 121,3 \\
\hline 27 & Cypr & 95 & 97 & 108 & 113,6 \\
\hline 28 & Malta & - & 55 & - & - \\
\hline
\end{tabular}

* dynamika w latach 2016/2012

Źródto: Opracowanie własne na podstawie danych Eurostatu [sbs_na_1a_se_r2] (11.04.2019).

Pod względem dynamiki, Słowacja - podobnie jak w przypadku liczby przedsiębiorstw - ponownie okazała się najlepszą unijną gospodarką. Powodem takiej sytuacji mogła być wspomniana sytuacja gospodarcza kraju. Poza tym, dynamikę liczby osób zatrudnionych można tłumaczyć kształtowaniem się m.in. dwóch wskaźników. Pierwszym z nich był ogólnym poziom wynagrodzeń brutto, który zgodnie z danymi Urzędu Statystycznego ${ }^{19}$ w latach 2011-2016 sukcesywnie rósł od 786 euro do 867 euro,

${ }^{19}$ Gospodarka Stowacji w pierwszym kwartale $2016 r$. Urząd Statystyczny RS, Narodowy Bank Słowacji, Ministerstwo Finansów Republiki Słowackiej, dostęp on-line dn. 16.05.2019 r.: https://bratyslawa.msz.gov.pl/ pl/c/MOBILE/wspolpraca_dwustronna/wspolpraca_gospodarcza/sytuacja_gospodarcza/gospodarka_slowacji_ w_pierwszym_kwartale_2016_roku 
co oznaczało progres na poziomie 10,3\%. Drugim powodem tak dużego wzrostu dynamiki liczby osób zatrudnionych w sektorze usług mogła być zmiana poziomu minimalnego wynagrodzenia w gospodarce Słowacji. Zgodnie z raportem Key figures on Europe 2017 edition. Statistical books ${ }^{20}$, w którym porównano dane z 2008 r. ze stanem w 2017 r., w kraju tym nastąpił jeden z większych wzrostów poziomu wynagrodzeń minimalnych (o 80\%) obok takich państw jak Bułgaria (109\%) czy Rumunia (99\%). W literaturze przedmiotu zauważa się trudności w zdefiniowaniu wpływu minimalnego wynagrodzenia na poziom zatrudnienia. Na jego negatywne przejawy wskazuje neoklasyczny model doskonale konkurencyjnego rynku pracy. Płaca minimalna z jednej strony jest to generatorem kosztów po stronie pracodawcy zmuszającym go do ograniczenia zatrudnienia lub nawet zwolnień, co w efekcie ogranicza dostęp do rynku pracy osobom w szczególnej sytuacji, np. młodym, długookresowo bezrobotnym czy też kobietom. Z drugiej strony interwencyjne podwyższanie płac przez państwo może doprowadzić do bezrobocia oraz wzrostu cen rynkowych. Wówczas pracodawcy będą zmniejszać zatrudnienie i ograniczać tworzenie nowych miejsc pracy $^{21}$. Taka sytuacja występuje $\mathrm{z}$ reguły na rynku pracy doskonale konkurencyjnym. Manning $^{22}$ oraz Krajewska ${ }^{23}$ zauważyli natomiast pozytywne skutki wzrostu płacy minimalnej. Według nich w gospodarce występują teoretycznie trzy sytuacje, w których wzrost płac minimalnych będzie miał pozytywne skutki. Po pierwsze rynek monopolistycznego pracodawcy, po drugie duże firmy, które niedostatecznie monitorują wydajność pracy i po ostatnie, gdy istnieją duże koszty mobilności związane $\mathrm{z}$ potencjalną zmianą pracy. W opozycji do teorii neoklasycznej stoi również teoria poszukiwań i dopasowań na rynku pracy. Zgodnie z jej założeniami poszukujący pracy podejmują większe wysiłki związane ze znalezieniem pracy, co jest efektem wzrostu płacy minimalnej ponad płacę równoważącą rynek ${ }^{24}$. Często jest tak, że płaca po okresie bezrobocia jest zbliżona do płacy minimalnej i stąd jej wzrost może spowodować, że bezrobotni chętniej podejmą pracę. Spowodował, że kraj ten znalazł się na jednym z ostatnich miejsc przeliczając liczbę zatrudnionych na przedsiębiorstwo. Gorsze były tylko Słowenia, Czechy, Grecja, Włochy oraz Portugalia.

\section{Wartość produkcji sektora usług krajów UE}

Do pełnego przedstawienia potencjału produkcyjnego sektora usług państw UE, poza opisanymi wcześniej dwoma wskaźnikami, wykorzystano również wskaźnik wartości

\footnotetext{
${ }^{20}$ Key figures on Europe 2017 edition. Statistical books. Eurostat. European Union, 2017, s. 75. Dostęp on-line dn. 16.05.2019 r.: https://publications.europa.eu/en/publication-detail/-/publication/ec0bf3c8-bac1-11e7-a7f801aa75ed71a1

${ }^{21}$ Nyk M.: Płaca minimalna wobec oczekiwań podażowej strony rynku pracy. Studia Prawno-Ekonomiczne, $\mathrm{t}$. XCV, 2015, s. 283; Hajduk K.: Płaca minimalna $w$ wybranych państwach Unii Europejskiej. Zeszyty Studenckie. Nasze Studia\&quot 9, 2019, s. 200-209; Golnau W: Znaczenie ptacy minimalnej dla funkcjonowania rynku pracy. Wydawnictwo Uniwersytetu Gdańskiego, Gdańsk, 2007, s. 69; Kozioł W.: Płaca minimalna $w$ świetle teorii kapitału ludzkiego. Studia Ekonomiczne, nr 161. Wydawnictwo Uniwersytetu Ekonomicznego w Katowicach, s. 65.

${ }^{22}$ Manning A.: The real thin theory: monopsony in modern labour markets, Labour Economics, 10(2), 2003, s. $105-131$.

${ }^{23}$ Krajewska A.: Refleksje o płacy minimalnej. Studia Prawno-Ekonomiczne, t. XCIV, 2015, s. 303-316.

${ }^{24}$ Petrongolo B., Pissarides C.A.: Scale effects in markets with search. The Economic Journal, Vol. 116, Issue 508, 2006, s. 21-44.
} 
produkcji wyrażony w mln euro. W jego zakresie zauważyć należy, że wśród pierwszych siedmiu państw UE wystąpiła tylko jedna zmiana w porównaniu do poprzednich klasyfikacji. Miejsce Polski zajęła Szwecja, w której w badanym sektorze wytworzono wartość produkcji na poziomie 231966 mln euro, co uplasowało ten kraj na siódmej pozycji (tab. 4). Polska w klasyfikacji tej znalazła się na 11 miejscu z wartością produkcji na poziomie $144303 \mathrm{mln}$ euro, ale w stosunku do wspomnianego kraju z Półwyspu Skandynawskiego dzieliło ją $87663 \mathrm{mln}$ euro, co stanowiło różnicę na poziomie $37,8 \%$.

Tabela 4. Wartość produkcji sektora usług w krajach UE (w mln euro)

\begin{tabular}{|c|c|c|c|c|c|}
\hline \multirow{2}{*}{ Lp. } & \multirow{2}{*}{$\begin{array}{l}\text { Wyszczególnieni } \\
\text { e }\end{array}$} & \multicolumn{3}{|c|}{ Rok } & \multirow{2}{*}{ Dynamika 2016/2008 (\%) } \\
\hline & & 2008 & 2012 & 2016 & \\
\hline 1 & Wielka Brytania & 952463 & 1023323 & 1269407 & 133,3 \\
\hline 2 & Niemcy & 797468 & 861746 & 1041357 & 130,6 \\
\hline 3 & Francja & 830828 & 912417 & 947400 & 114,0 \\
\hline 4 & Włochy & 575811 & 575391 & 602323 & 104,6 \\
\hline 5 & Hiszpania & 341553 & 306091 & 354580 & 103,8 \\
\hline 6 & Holandia & 282826 & 290585 & 342452 & 121,1 \\
\hline 7 & Szwecja & 168686 & 207418 & 231966 & 137,5 \\
\hline 8 & Belgia & 150473 & 182603 & 216531 & 143,9 \\
\hline 9 & Dania & 113662 & 147424 & 173884 & 153,0 \\
\hline 10 & Irlandia & 81817 & 125940 & 158076 & 193,2 \\
\hline 11 & Polska & 115606 & 115570 & 144303 & 124,8 \\
\hline 12 & Austria & 96475 & 104775 & 117312 & 121,6 \\
\hline 13 & Finlandia & 68064 & 77033 & 85080 & 125,0 \\
\hline 14 & Czechy & 70282 & 66821 & 73140 & 104,1 \\
\hline 15 & Portugalia & 68658 & 59547 & 66502 & 96,9 \\
\hline 16 & Rumunia & 37450 & 36760 & 47941 & 128,0 \\
\hline 17 & Grecja & 57925 & 39711 & 41357 & 71,4 \\
\hline 18 & Węgry & 34554 & 31701 & 38354 & 111,0 \\
\hline 19 & Luksemburg & 17533 & 20402 & 36751 & 209,6 \\
\hline 20 & Słowacja & 16477 & 22130 & 30639 & 186,0 \\
\hline 21 & Bułgaria & 14963 & 15413 & 19502 & 130,3 \\
\hline 22 & Chorwacja & 18242 & 14507 & 18490 & 101,4 \\
\hline 23 & Słowenia & 14030 & 13278 & 15209 & 108,4 \\
\hline 24 & Litwa & 11557 & 11642 & 14602 & 126,3 \\
\hline 25 & Estonia & 8451 & 10221 & 11155 & 132,0 \\
\hline 26 & Łotwa & 9302 & 9689 & 10074 & 108,3 \\
\hline 27 & Cypr & 7280 & 7994 & 9881 & 135,7 \\
\hline 28 & Malta & 3064 & 4419 & - & - \\
\hline
\end{tabular}

Źródło: Opracowanie własne na podstawie danych Eurostatu [sbs_na_1a_se_r2] (11.04.2019).

Wśród krajów z pierwszej „siódemki” najwyższy poziom dynamiki zanotowano we wspomnianej Szwecji. W badanym okresie nastąpił wzrost wartości produkcji sektora usług o 37,5\%. Większą dynamiką analizowanego wskaźnika odznaczały się m.in. kraje takie, jak: Belgia, Dania, Słowacja, Irlandia czy Luksemburg, w którym przyrost w 2016 r. w stosunku do 2008 r. był ponad dwukrotnie większy i wyniósł 209,6\%. Pośrednią przyczyną tak dużego wzrost wartości produkcji mógł być niewielki rozmiar rynku wewnętrznego Luksemburga, co wywołało naturalną konieczność podejmowania działań w skali międzynarodowej, a także lokalizacja tego państwa w centrum Europy. Z tego względu w państwie tym jedną z lepiej rozwiniętych sekcji 
usługowych jest transport i logistyka. Jednak największą wartość produkcji generuje sekcja M związany z działalnością profesjonalną, naukową i techniczną, która w 2016 r. stanowiła 51,4\% wartości produkcji całego sektora usług. W jej ramach wymienić można przykładowo prace badawcze i ekspertyzy: „Luxembourg Institute of Health”, czy też „Centre for Systems Biomedicine”, obie z zakresu biomedycyny. Kraj Beneluksu uczestniczy także w programach telekomunikacyjnych, obserwacyjnych, technologicznych i nawigacyjnych $\mathrm{w}$ ramach akcesji do Europejskiej Agencji Kosmicznej ${ }^{25}$.

Należy wskazać na spadek wartości produkcji w badanym okresie w przypadku dwóch krajów członkowskich. W Portugalii dynamika tego wskaźnika w 2016 r. w stosunku do 2008 r. była niższa o $3,1 \%$, w Grecji natomiast o $28,6 \%$. W obu tych państwach sytuacja była i tak korzystniejsza niż w 2012 r., a w znacznej mierze wynikała z kryzysu gospodarczego, który szczególnie dotknął Grecję. Od 2006 r. aż do 2013 r. większość wskaźników ekonomicznych w tym państwie była niekorzystna. Nawet, gdyby powszechnie znany kryzys w Grecji nie wystapił, to i tak jest to jedna ze słabszych gospodarek krajów UE pod względem konkurencyjności, dodatkowo ze stosunkowo słabym poziomem integracji międzynarodowej. Jedną ze specyficznych cechy tego kraju jest notoryczna dominacja sektora publicznego w generowaniu produktu krajowego brutto (PKB), którego udział w 2013 r. wynosił 40\%. Dodając do tego, bardzo duże uzależnienie gospodarki Grecji od usług żeglugowych oraz turystyki, a także wspomniany kryzys, uzasadnionym staje się najniższy poziom dymniki wskaźnika wartości produkcji sektora usług $-71,4 \%^{26}$. Polski sektor usług uplasował się mniej więcej $\mathrm{w}$ połowie zestawienia. W stosunku do Wielkiej Brytanii, państwa liderującego w UE pod względem wartości produkcji, Polska wytworzyła aż o 1125104 mln euro mniejszą wartość produkcji, co stanowiło różnicę na poziomie $88,6 \%$.

$\mathrm{W}$ celu syntetycznego przedstawienia wszystkich omawianych do tej pory wskaźników, zaprezentowano je na rysunku 1 wraz z podziałem na poziomy takie jak: niski, średni oraz wysoki. Poziom wszystkich wskaźników (liczba przedsiębiorstw, liczba zatrudnionych, wartość produkcji) w sektorze usług państw UE był bardzo zbliżony do siebie. Wystąpiły jedynie różnice w przypadku Hiszpanii, w której odnotowano liczbę przedsiębiorstw na średnim poziomie, na niskim zaś - liczbę zatrudnionych oraz wartość produkcji. Kolejnymi dwoma krajami, które były nieco zróżnicowane $\mathrm{w}$ zakresie poziomu wskaźników były Polska oraz Szwecja. Pierwsze $\mathrm{z}$ wymienionych państw cechowało się średnim poziomem liczby przedsiębiorstw oraz osób zatrudnionych, natomiast wartość produkcji uznana została jako niska. Szwecja zaś odznaczała się niskimi poziomami w ramach zatrudnienia i liczby przedsiębiorstw, ale wartość produkcji zaliczona została do średniego przedziału.

\footnotetext{
${ }^{25}$ Thelen C.: Gospodarka Luksemburga - otwarta, dynamiczna, pewna. Broszura Luksemburskiej Izby Gospodarczej, 2018, s. 23-25, 32.

26 http://rig.katowice.pl/files/Wsp\%C3\%B3\%C5\%82praca\%20Mi\%C4\%99dzynarodowa/40.\%20Grecja.pdf, dostęp on-line dn. 16.05.2019 r.
} 
Liczba przedsiębiorstw w sektorze usług w krajach UE (w tys.)



Poziom wskaźnika:

brak danych

$(0-446,2>$

$(446,2-949,2>$

$(949,2-1670,1>$

Liczba zatrudnionych w sektorze usług w krajach UE (w tys.)



Poziom wskaźnika:

$\square$ brak danych

$(0-2296,0>$

(2 296,0 - 5 549,5>

(5 549,5 - $12591,0>$ 


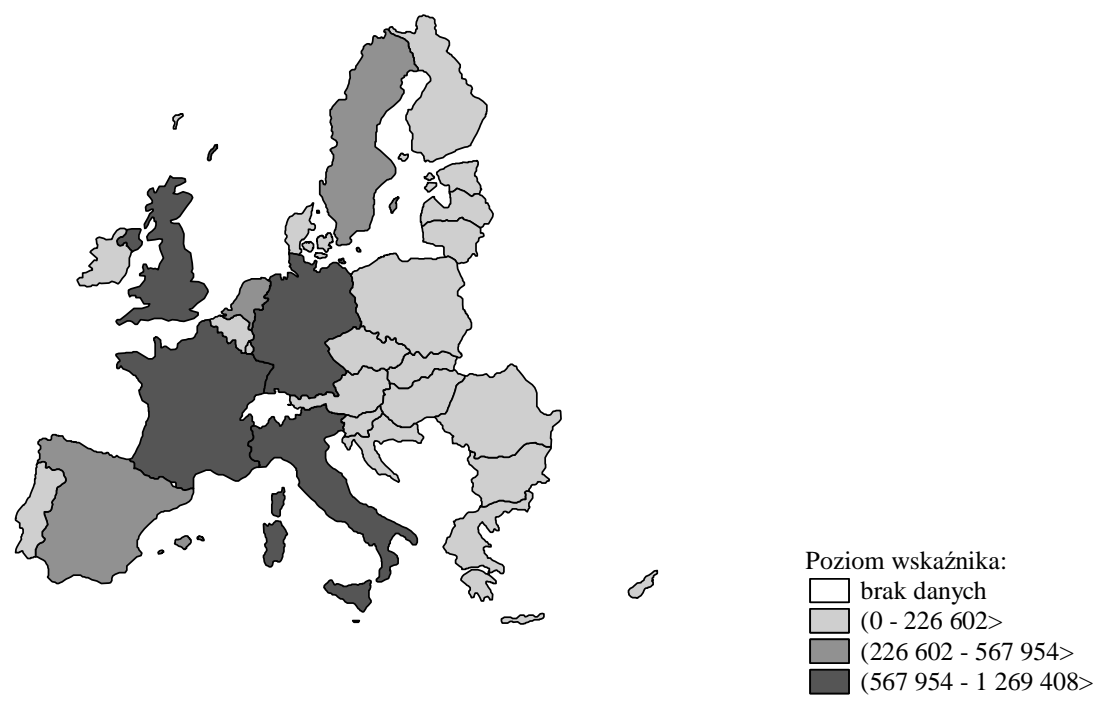

Rysunek 1. Poziom wskaźników charakteryzujących sektor usług w krajach UE w 2016 r.

Źródło: Opracowanie własne na podstawie danych Eurostatu [sbs_na_1a_se_r2] (11.04.2019) z wykorzystaniem oprogramowania Statistica.

\section{Podsumowanie}

Celem opracowania była identyfikacja potencjału produkcyjnego państw UE. W tym kontekście oraz na podstawie wykorzystanych metod badawczych należy zauważyć, że najlepszymi wynikami w zakresie interpretowanych indykatorów odznaczało się siedem państw. W zakresie liczby przedsiębiorstw oraz ilości zatrudnionych osób były to: Niemcy, Wielka Brytania, Francja, Włochy, Hiszpania, Holandia oraz Polska. Dodatkowo, intuicyjnie można zauważyć zależność, że im większa była ludność danego państwa, tym większe było zatrudnienie w sektorze usług. W odniesieniu do trzeciego analizowanego wskaźnika, jakim była wartość produkcji, tylko ostatnie z wymienionych państw zastąpiła Szwecja. Największą dynamikę wartości produkcji, liczby przedsiębiorstw oraz zatrudnienia zidentyfikowano w Szwecji, Irlandii oraz Luksemburgu.

Dodatkowo należy zauważyć, że analiza potencjału produkcyjnego sektorów usługowych spowodowała, że możliwe stało się podzielenie państw UE na dwie części zachodnią i wschodnią, a granicą tego podziału okazała się być zachodnia granica Polski. Generalnie na podstawie zebranego i syntetycznie opracowanego materiału badawczego można stwierdzić, że weryfikowany potencjał był na wyższym poziomie w krajach na zachód od Polski. Druga część Europy cechowała się zdecydowanie niższymi indykatorami. Wśród krajów wschodniej partii UE na uwagę zasługuje słowacki sektor usług z uwagi na dynamikę zmian omawianych wskaźników. Tempo przyrostu liczby przedsiębiorstw, wielkości zatrudnienia i wartości produkcji w Słowacji 
było największe wśród krajów we wschodniej części UE, a w przypadku pierwszych dwóch wielkości największe w całej Europie. W badanych latach 2008-2016, Słowacja była krajem o zdecydowanie największym przyroście liczby przedsiębiorstw oraz zatrudnionych $\mathrm{w}$ sektorze usług. Taki stan wynikać mógł z trzech przesłanek natury ekonomicznej. Po pierwsze wpływ na to miała deregulacja gospodarki, po drugie był to efekt kryzysu gospodarczego. Po ostatnie gwałtowny wzrost liczby podmiotów, który nastąpił szczególnie w latach 2008-2012 był efektem akcesji Słowacji do strefy wspólnej waluty euro w 2009 r. Takie przyrosty odnotowano jeszcze w krajach, które w badanym okresie przyjęły wspólną walutę, tj. Estonia, Litwa i Łotwa. Na przykładzie wspomnianych państw można wnioskować, że wzrost potencjału produkcyjnego w zakresie liczby przedsiębiorstw oraz zatrudnienia był związany z przystąpieniem danego państwa do strefy euro. Przypadek słowackiego sektora usług nie był więc odosobniony w UE. Jak wskazano, wszystkie wymienione państwa reprezentowały wschodnią część Europy, a mimo to, skala zmian liczby zarejestrowanych firm usługowych była większa niż w przypadku innych państw tej części kontynentu, np. Polski, Czech, Bułgarii, Rumunii, Węgier czy Grecji. Należy dodać, że ta pozytywna dynamika odnotowana na Słowacji, w Estonii, na Litwie czy Łotwie miała miejsce przy jednoczesnym relatywnie niskim poziomie badanych wskaźników w stosunku do pozostałych krajów UE.

Zaprezentowane w opracowaniu wyniki badań dotyczące potencjału produkcyjnego sektora usług w przyszłości mogą zostać rozszerzone o efekty wykorzystania tego potencjału w praktyce, a więc o analizę produktywności. Dodatkowo niezwykle istotnym i znaczącym aspektem w zakresie poruszanej problematyki może być wpływ innowacyjności (postępu technicznego) na produktywność. $\mathrm{Na}$ znaczenie innowacyjności w produktywności (w tym także sektora usług) wskazano niejednokrotnie w opracowaniu.

Należy nadmienić, że zaprezentowane w opracowaniu wyniki są jedynie częścią większych badań dotyczących produktywności sektora usług w państwach UE. Jednocześnie przedstawiony $\mathrm{w}$ artykule materiał badawczy nie ma charakteru statystycznego i nie może być podstawą do formułowania wniosków ogólnych, jednakże może stanowić pewien punkt odniesienia $w$ pogłębionych badaniach nad tą problematyką.

\section{Bibliografia}

Bartkowiak R.: Historia myśli ekonomicznej. Wydawnictwo PWE, Warszawa, 2003.

Cyrek M.: Wspótczesne zmiany struktury sektora ustugowego. [w:] Funkcjonowanie gospodarki polskiej w warunkach integracji i globalizacji, red. D. Kopycińska, Katedra Mikroekonomii, Uniwersytet Szczeciński, Szczecin 2005, s. 279-289.

Dudziak A., Piekarski W., Stoma M.: Zarzadzanie produktywnościa a ryzyko operacyjne dziatalności polskich przedsiębiorstw, monografia pokonferencyjna: „Innowacje w Zarządzaniu i Inżynierii Produkcji”, Zakopane, 2014, s. 237-246.

Eurostat [sbs_na_1a_se_r2], dostęp on-line dn. 21.03.2019 r.

Golnau W: Znaczenie płacy minimalnej dla funkcjonowania rynku pracy. Wydawnictwo Uniwersytetu Gdańskiego, Gdańsk, 2007.

Gospodarka Stowacji w pierwszym kwartale 2016 r. Urząd Statystyczny RS, Narodowy Bank Słowacji, Ministerstwo Finansów Republiki Słowackiej, dostęp on-line dn. 16.05.2019 r.: 
https://bratyslawa.msz.gov.pl/pl/c/MOBILE/wspolpraca_dwustronna/ wspolpraca_gospodarcza/sytuacja_gospodarcza/gospodarka_slowacji_w_pierwszym_kwartale_20 16_roku.

http://rig.katowice.pl/files/Wsp\%C3\%B3\%C5\%82praca\%20Mi\%C4\%99dzynarodowa/40.\%20Gre cja.pdf, dostęp on-line dn. 16.05.2019 r.

https://wynagrodzenia.pl/gus/dane-wojewodzkie/polska, dostęp on-line dn. 17.05.2019 r.

Jarmołowicz W., Knapińska M.: Koszty i produktywność pracy w Polsce i Unii Europejskiejelementy analizy porównawczej. Studia Ekonomiczne, 196. Wydawnictwo Uniwersytetu Ekonomicznego w Katowicach, 2014, s. 13.

Key figures on Europe 2017 edition. Statistical books. Eurostat. European Union, 2017. Dostęp on-line dn. 16.05.2019 r.: https://publications.europa.eu/en/publication-detail//publication/ec0bf3c8-bac1-11e7-a7f8-01aa75ed71a1.

Kozioł L.: Metodyczne aspekty oceny produktywności. Zeszyty Naukowe Akademii Ekonomicznej w Krakowie, 727, 2007, s. 25-40.

Kozioł W.: Ptaca minimalna $w$ świetle teorii kapitału ludzkiego. Studia Ekonomiczne, 161. Wydawnictwo Uniwersytetu Ekonomicznego w Katowicach, 2013, s. 63-72.

Krajewska A.: Refleksje o ptacy minimalnej. Studia Prawno-Ekonomiczne, t. XCIV, 2015, s. 303-316 .

Manning A.: The real thin theory: monopsony in modern labour markets, Labour Economics, 10(2), 2003, s. 105-131.

Nyk M.: Ptaca minimalna wobec oczekiwań podażowej strony rynku pracy. Studia PrawnoEkonomiczne, t. XCV, 2015, s. 289-300.Petrongolo B., Pissarides C.A.: Scale effects in markets with search. The Economic Journal, Vol. 116, Issue 508, 2006, s. 21-44.

Skórska A.: Determinanty $i$ perspektywy rozwoju sektora ustug $w$ Polsce - zmiany wewnatrzsektorowe [w:] Prace Komisji Geografii Przemysłu Polskiego Towarzystwa Geograficznego, 30(4). Przemiany sektora usług transportowych i turystycznych, red. Z. Zioło, T. Rachwała, Wydawnictwo Uniwersytetu Pedagogicznego im. Komisji Edukacji Narodowej w Krakowie, Kraków, 2016, s. 7-20.

Smoleński S.: Zarzadzanie produktywnościa w przedsiębiorstwie. Wydawnictwo Ośrodek Postępu Organizacyjnego, Bydgoszcz, 2000.

Thelen C.: 2018. Gospodarka Luksemburga - otwarta, dynamiczna, pewna. Broszura Luksemburskiej Izby Gospodarczej.

Uliszak R., Grad N.: Innowacyjność kluczem rozwoju firmy IBM. Prace Komisji Geografii Przemysłu Polskiego Towarzystwa Geograficznego, 20/2012, s. 40-53.

Węgrzyn G., Miłaszewicz D.: Sektor ustug $w$ gospodarce opartej na wiedzy - analiza porównawcza. Studia i Prace Wydziału Nauk Ekonomicznych i Zarządzania Uniwersytetu Szczecińskiego 47/3, 2017, s. 433-444.

Wierzbicka W.: Produktywność pracy przedsiębiorstw prywatnych $w$ Polsce - ujęcie regionalne. Zeszyty Naukowe Uniwersytetu Przyrodniczo-Humanistycznego w Siedlcach, Seria: Administracja i Zarządzanie, 97, 2013, s. 241-255.

Wysocki F. Lira J.: Statystyka opisowa. Wydawnictwo Akademii Rolniczej im. Augusta Cieszkowskiego, Poznań, 2005.

Zielińska-Głębocka A.: Analiza produkcyjności polskiego przemystu. Aspekty metodyczne i empiryczne. Ekonomista, 3/2004, s. 335-358.

\section{Abstract}

This study addresses widely understood issues regarding productivity in the service sector and also extends to aspects of innovativeness within the sector. Results of the research presented in the article are based on secondary data gathered from the European base of statistical knowledge Eurostat. The research also aims to evaluate the role and meaning of the service sector in national 
economies of EU countries in the $21^{\text {st }}$ century. From this perspective, one of the goals was to identify the production potential within the service sectors of EU members. Methods used to achieve this goal included secondary data analysis, a review of domestic and foreign literature on the subject and basic statistical methods (standard deviation, arithmetic average), especially when aggregating countries into groups by specific production potential of service sectors.

Taking into consideration all the indicators of production potential, which were analysed in the study (number of enterprises, number of people hired, value of production) for EU countries, the service sectors which had the highest production potential were found within: France, Great Britain, Germany, Italy and Spain - with the exception of production value. Poland was classified into the group of countries with average potential, except for the indicator identifying the value of production, which had a low level.

Key words: production potential, productivity, services sector, EU member states

JEL Codes: D24, L80, O52

Informacje o autorze:

dr Kamil Decyk

Uniwersytet Warmińsko-Mazurski w Olsztynie,

Wydział Nauk Ekonomicznych,

Katedra Ekonomiki Przedsiębiorstw

ul. Oczapowskiego 4

10-719 Olsztyn

e-mail:kamil.decyk@uwm.edu.pl,

ORCID 0000-0002-8590-4185 